\title{
Plant Regeneration from Unpollinated Ovules of Sugar Beet (Beta vulgaris L.) on Growing Media with Different Carbohydrates
}

\author{
Magdalena Tomaszewska-Sowa' ${ }^{1}$ (D) Anna J. Keutgen² ${ }^{2}$
}

Received: 7 January 2021 / Accepted: 10 March 2021 / Published online: 3 August 2021

(C) The Author(s) 2021

\begin{abstract}
Sugar beet (Beta vulgaris L.) is referred to as a strategic species due to its exceptional economic and functional importance. Sugar beet is cultivated in order to provide material for sugar production as it is the world's second source after sugar cane. However, in this species, the regeneration of haploid shoots is difficult in comparison to other cultures or isolated microspores. Haploid plants of sugar beet can be derived from in vitro culture mostly via gynogenesis. Therefore, the aim of this research has been to increase the effectiveness of shoot formation from unpollinated sugar beet ovules by optimising the regeneration technique via induced gynogenesis. Various types and concentrations of chosen carbohydrates in media were evaluated. The Murashige and Skoog medium containing $4.4 \mu \mathrm{mol} / \mathrm{L}$ of 6-benzylaminopurine was solidified by $0.7 \%$ of agar and enriched with either sucrose $(0.06 \mathrm{~mol} / \mathrm{L}$ or $0.09 \mathrm{~mol} / \mathrm{L})$, glucose $(0.09 \mathrm{~mol} / \mathrm{L})$, fructose $(0.09 \mathrm{~mol} / \mathrm{L})$, maltose $(0.09 \mathrm{~mol} / \mathrm{L})$ or with a combination of sucrose $(0.04 \mathrm{~mol} / \mathrm{L})$ and mannitol $(0.04 \mathrm{~mol} / \mathrm{L})$ or with sucrose $(0.04 \mathrm{~mol} / \mathrm{L})$ and fructose $(0.04 \mathrm{~mol} / \mathrm{L})$. The control medium contained $0.09 \mathrm{~mol} / \mathrm{L}$ sucrose without any cytokinins. Of all the analysed media, the best for shoot regeneration turned out to be the media with $4.4 \mu \mathrm{mol} / \mathrm{L}$ 6-benzylaminopurine, solidified with $0.7 \%$ agar, additionally
\end{abstract}

Anna J. Keutgen

anna.keutgen@boku.ac.at

Magdalena Tomaszewska-Sowa

magda@utp.edu.pl

1 Department of Agricultural Biotechnology, University of Science and Technology in Bydgoszcz, Bernardyńska 6, 85-029 Bydgoszcz, Poland

2 University of Natural Resources and Life Sciences Vienna (BOKU), Gregor-Mendel-Str. 33, 1180 Vienna, Austria containing $0.09 \mathrm{~mol} / \mathrm{L}$ glucose or $0.06 \mathrm{~mol} / \mathrm{L}$ sucrose. On those media, over three-fold more shoots compared with the control medium were produced.

Keywords Gynogenesis - Sugar beet · Ovules · Carbohydrates

\section{Introduction}

Sugar beet (Beta vulgaris L.) belongs to the economically very important crops plants, where biological progress in the form of new varieties with performance characteristics far superior compared to the existing ones has been made possible to a large extent by using in vitro culture techniques, in particular the production of haploids and doubled haploids as pure homozygous lines, thus significantly shortening the sugar beet breeding cycle (Mezei et al. 2006). In nature, the spontaneous development of haploids is a very rare phenomenon, which does not allow to use it on a wider scale in practice. For instance, in the case of sugar beet, it would take some years to achieve homozygous pure lines as a starting material for further studies (Musiał and Przywara 2001; Pazuki et al. 2018). Furthermore, in sugar beet, the regeneration of haploidal shoots under in vitro conditions from the anthers or isolated microspores (androgenesis way) is reported to be difficult. Because of its great economic importance, an intensive research project to provide effective methods for the propagation of plants from tissue and cell explants and the development of new varieties has been undertaken. As a result, the acquisition of haploidal sugar beets and thereafter of doubled haploids (DH) is mainly achieved by gynogenesis (Musiał and Przywara 2001; Pazuki et al. 2018). Fortunately, the sugar beet belongs to the few plants 
where gynogenesis is sufficiently effective to be used in breeding programmes. Using unfertilised ovules allows the acquisition of fully homozygous lines in one generation from the heterozygous material (Pazuki et al. 2018). The regeneration of ovules by the gynogenesis technique occurs mainly by indirect organogenesis. Callus formation in the course of gynogenesis is an unfavourable process, as it is associated with the possibility of somaclonal variation (Yang and Zhou 1982; Musiał and Przywara 2001). The presence of diploids among the regenerants obtained from the ovules may therefore be a result of an increased level of DNA during callus development and differentiation, or it may indicate that the shoots originated from somatic cells. However, the effectiveness of gynogenesis induction depends on several factors (Musiał and Przywara 2001) such as the regenerative capacity of the genotype (Van Geyt et al. 1987; Wremeth Weich and Levall 2003), developmental stage of the ovary sac (Lux et al. 1990; Wang et al. 1991; Gośka 1997; Gürel et al. 2000), the age and the growth conditions of the mother plant (Doctrinal et al. 1989), medium composition (Doctrinal et al. 1990; Yu 1992; Tomaszewska-Sowa 2012, Taghipour et al. 2013; Tomaszewska-Sowa et al. 2017; Tomaszewska-Sowa and Olszewska 2019) and culture conditions (Pazuki et al. 2018) as well as on the interactions of multiple factors (Tomaszewska-Sowa et al. 2017; Pazuki et al. 2018). The first reported haploids from sugar beet were obtained from ovaries isolated from male-sterile shoots (Hosemans and Bossoutrot 1983), and thereafter, doubled haploid homozygous lines were achieved by using haploids and colchicine (Hosemans and Bossoutrot 1985).

The factor, which considerably determines the process and success of gynogenesis is the selection of the appropriate medium. To induce the development of haploid embryos, the Murashige and Skoog medium (MS) (Murashige and Skoog 1962) or a modified MS medium is most frequently applied. Changes in the medium composition cover the type and content of carbohydrates and a combination of adequately concentrated growth regulators (Tomaszewska-Sowa et al. 2017). Carbohydrates are a very essential compound of the media. They constitute the primary source of carbon and energy, and they regulate the osmotic potential. The most frequently applied carbohydrate for in vitro plant breeding is sucrose. It is a disaccharide acting as a signalling molecule and showing a high solubility in water. It easily migrates through the plasmatic membrane (Javed and Ikram 2008; Baskaran and Jayabalan 2005). Sucrose affects the volumetric cell growth by regulating the osmotic pressure, thus increasing the growth rate and the size of the seedlings (Sumaryono et al. 2012). Such a carbohydrate is added to media at various concentrations, e.g. $0.9 \%$ (Tomaszewska-Sowa et al. 2017), $1 \%$ (Cappadocia et al. 1988) or 3\% (Kim et al. 1999). Higher sucrose concentrations ( $12 \%$ or $14 \%$ ) are used to induce gynogenesis in plants of the Graminaceae family, e.g. in barley Hordeum vulgare L. (San Noeum 1976). In cultures of immature ovules or ovaries, sucrose concentrations of 3\% (Gośka and Jassem 1988; Van Geyt et al. 1987), 6\% (Yu 1992), 8\% (Bossoutrot and Hosemans 1985) or $10 \%$ (Gürel et al. 2000), respectively, are applied. In other cultures of cereal plants, a commonly applied carbohydrate is maltose (Gonzalez and Youve 2000). It was used in cultures of wheat Triticum turgidum Desf. (Gonzalez et al. 2001; Slama-Ayed and Slim-Amara 2007) and also in that of the Indian plant babći Psoralea corylifolia L. (Chand and Sahrawat 2007). The presence of maltose in the medium prevents the accumulation of glucose, which is a result of sucrose hydrolysis. Accumulated glucose increases the osmotic potential in the medium and inhibits processes of embryogenesis (Roberts-Ochschlager et al. 1990). Thus, the objective of this research has been to determine the type and concentration of different carbohydrates suitable for plant regeneration in unpollinated ovules culture of sugar beet Beta vulgaris L., to be applied on a large scale.

\section{Material and Methods}

The research material consisted of sugar beet plants (Beta vulgaris L.) derived from the process of in vitro propagation of a single diploid donor plant of genotype 0170 originated from the Kutno Sugar Beet Breeding Centre (the Plant Breeding Station at Straszków, Poland). For the preparation, generative shoots segments of $5 \mathrm{~cm}$ length were used. At first, they were sterilised with ethanol (70\% water solution $\mathrm{v} / \mathrm{v}$ ) for $1 \mathrm{~min}$, then with calcium hyperchlorite (3\% water solution $\mathrm{v} / \mathrm{v}$ ) for $20 \mathrm{~min}$ and finally rinsed with sterile pure water to remove the chemicals. Thereafter, the ovules were isolated under sterile conditions from 3 to 4 closed flower buds located on a single generative shoot, just above of a bud in the anthesis period. The culture of the isolated ovules was maintained in a liquid MS medium containing $4.4 \mu \mathrm{mol} / \mathrm{L}$ 6-benzylaminopurine (BAP) and $0.09 \mathrm{~mol} / \mathrm{L}$ of sucrose, $100 \mathrm{mg} / \mathrm{L}$ inositol and $0.4 \mathrm{mg} / \mathrm{L}$ thiamine in the proportion of 30 ovules in $25 \mathrm{~mL}$ of the medium (Fig. 1). The culture was kept for 12 weeks at a temperature of $24{ }^{\circ} \mathrm{C}$ and under a 16-h photoperiod with a light intensity of $40 \mu \mathrm{mol} \mathrm{m} \mathrm{m}^{-2}$. $\mathrm{s}^{-1}$ by permanent shaking at $150 \mathrm{rpm}$ on a shaker (Lab Line Instruments, USA).

The regenerating structures from the liquid medium were passaged onto MS medium containing $4.4 \mu \mathrm{mol} / \mathrm{L}$ BAP, agar $(0.7 \%)$ as well as different variants of carbohydrates, including sucrose at the concentrations of $0.09 \mathrm{~mol} / \mathrm{L}$ or $0.06 \mathrm{~mol} / \mathrm{L}$, glucose $(0.09 \mathrm{~mol} / \mathrm{L})$, fructose 
Fig. 1 Stages of Beta vulgaris ovules regeneration: cut-off of generative shoot fragment (a), a flower bud with isolated ovule (b), regenerating ovules in liquid MS medium (c)


(0.09 mol/L), maltose $(0.09 \mathrm{~mol} / \mathrm{L})$ or combinations of sucrose $(0.04 \mathrm{~mol} / \mathrm{L})$ with mannitol or fructose (both $0.04 \mathrm{~mol} / \mathrm{L})$. As the control medium served MS medium without cytokinins containing agar $(0.7 \%)$ and sucrose ( $0.09 \mathrm{~mol} / \mathrm{L})$. Each variant of the experiment comprised the development of 60 structures (3 replications, 20 explants each), placed at $24^{\circ} \mathrm{C}$ and exposed to a $16 / 8-\mathrm{h}$ light/dark cycle with a light intensity of about $40 \mu \mathrm{mol} \mathrm{m} \mathrm{m}^{-2} \mathrm{~s}^{-1}$. Two additional passages on the same medium were performed in order to promote shoot development.

To induce rhizogenesis, the shoots were transferred onto MS medium supplemented with $14.8 \mu \mathrm{mol} / \mathrm{L}$ indole-3-butyric acid (IBA) and $0.049 \mu \mathrm{mol} / \mathrm{L} 6-(\gamma, \gamma$-dimethylallylamino)purine (2iP). The rooted plants were cleaned from agar and transferred onto a sterilized medium (a mixture of peat moss and perlite in proportion of $3: 2 \mathrm{v} / \mathrm{v}$ ) and placed in the glasshouse under the foil tunnel $\left(25^{\circ} \mathrm{C} \pm 2{ }^{\circ} \mathrm{C}\right)$. The relative humidity $\mathrm{RH}$ was gradually reduced from $95 \%$ to the ambient one during the acclimatization time of a few weeks. After the acclimatization, the rooted shoots were planted out in the field.

In the experiment, the following parameters were investigated: the number of explants forming shoots or callus, shoot-forming effectiveness on respective media and rooting effectiveness.

The applicability of respective types of media to induce the processes of regeneration of sugar beet plants was evaluated based on the number of the shoots produced and rooted plantlets. The results were compared with the corresponding data for the control medium. Statistical analyses were performed with Spearman's rank correlation test, the key objective of which has been to compare the media in terms of their effectiveness in the process of shoot formation and rooting.

The statistical analysis was performed at two stages, aiming at a comparison of the effect of the media on plant regeneration and root formation, namely a comparison of the media in terms of their composition. The comparison of the effect of the media grouped by a similar media composition on the regeneration of shoots and plant rooting was performed applying cluster analysis. The Euclidean distances were calculated as the measure of similarity (dissimilarity) using the formula:
$D=\sqrt{\sum\left(x_{i}-y_{i}\right)^{2}}$

where $x_{i}$-is the corresponding value of the first medium, $y_{i}$-is the corresponding value of the second medium and, $i$-is the parameter studied with $i=1$ being the number of shoots regenerated on a specific medium and $i=2$ being the number of rooted plants regenerated on a specific medium.

The results of the calculated Euclidean distances were collected in a matrix. The matrix of the Euclidean distances was used to evaluate the level of similarity between the media grouped according to their composition, viz. the applied carbohydrates.

Performing the analysis, the sets of the values of the Euclidean distances were transposed onto a 9-point ordinal scale, and the successive values were provided with the quality terms. A new scale of intensity of the similarity between the media has been created:

1 - similarity of a very high intensity;

5-similarity of an average intensity;

9 - similarity of a very poor intensity.

Tables 3 and 4 presenting the results of the analysis of the Euclidean distances values are provided with the above similarity intensity scale, which provides essential information for their interpretation.

\section{Results}

The effects of various carbohydrates on the morphogenetic processes in beet ovules were investigated. Glucose $(0.09 \mathrm{~mol} / \mathrm{L})$ and sucrose $(0.06 \mathrm{~mol} / \mathrm{L})$ intensified the processes of ovules regeneration (Table 1), where the highest effectiveness of ovules regeneration was recorded after the first four weeks of the culture (Table 1).

The shoots produced in the passages for glucose $(0.09 \mathrm{~mol} / \mathrm{L})$ and sucrose $(0.06 \mathrm{~mol} / \mathrm{L})$ showed the best habitus and were the largest in number, also compared with the control. The other variants also resulted in shoot formation. However, the shoots often were inadequately formed (wide leaf laminas), resembled the form of rosettelike deformed leaves and frequently underwent hyperhydricity (previously known as vitrification). Some of the 
Table 1 Efficiency of shoots and callus tissue formation depending on the carbohydrate composition in the media

\begin{tabular}{|c|c|c|c|c|c|}
\hline $\begin{array}{l}\text { Media } \\
\text { number }\end{array}$ & Medium composition & $\begin{array}{l}\text { Number of explants forming } \\
\text { shoots after } 4 \text { weeks of } \\
\text { culture }\end{array}$ & $\begin{array}{l}\text { Number of explants forming } \\
\text { callus after } 4 \text { weeks of } \\
\text { culture }\end{array}$ & $\begin{array}{l}\text { Number of } \\
\text { regenerating } \\
\text { explants }\end{array}$ & $\begin{array}{l}\% \text { of regenerative structures } \\
\text { compared to total amount of } \\
\text { explants }\end{array}$ \\
\hline 1 & $\begin{array}{l}\text { Sucrose } 0.09 \mathrm{~mol} / \mathrm{L} \\
\quad \text { (control) }\end{array}$ & 17 & 2 & 19 & 31.7 \\
\hline 2 & $\begin{array}{l}\text { Sucrose } 0.09 \mathrm{~mol} / \\
\mathrm{L}+\mathrm{BAP}\end{array}$ & 19 & 6 & 25 & 41.7 \\
\hline 3 & $\begin{array}{l}\text { Sucrose } 0.06 \mathrm{~mol} / \\
\mathrm{L}+\mathrm{BAP}\end{array}$ & 20 & 3 & 23 & 38.3 \\
\hline 4 & $\begin{array}{l}\text { Glucose } 0.09 \mathrm{~mol} / \\
\mathrm{L}+\mathrm{BAP}\end{array}$ & 25 & 3 & 28 & 47.0 \\
\hline 5 & $\begin{array}{l}\text { Fructose } 0.09 \mathrm{~mol} / \\
\mathrm{L}+\mathrm{BAP}\end{array}$ & 10 & 3 & 13 & 21.7 \\
\hline 6 & $\begin{array}{l}\text { Maltose } 0.09 \mathrm{~mol} / \\
\mathrm{L}+\mathrm{BAP}\end{array}$ & 8 & 1 & 9 & 15.0 \\
\hline 7 & $\begin{array}{l}\text { Sucrose } 0.04 \mathrm{~mol} / \\
\mathrm{L}+\text { mannitol } \\
0.04 \mathrm{~mol} / \mathrm{L}+\mathrm{BAP}\end{array}$ & 10 & 0 & 10 & 16.7 \\
\hline 8 & $\begin{array}{l}\text { Sucrose } 0.04 \mathrm{~mol} / \\
\mathrm{L}+\text { fructose } \\
0.04 \mathrm{~mol} / \mathrm{L}+\mathrm{BAP}\end{array}$ & 9 & 1 & 10 & 16.7 \\
\hline
\end{tabular}

BAP $-4.4 \mu \mathrm{mol} / \mathrm{L}$ 6-benzylaminopurine

carbohydrates applied in the medium limited the processes of organogenesis during the regeneration of ovules, e.g. in the case of maltose $(0.09 \mathrm{~mol} / \mathrm{L})$ with $\mathrm{BAP}$ or sucrose $(0.04 \mathrm{~mol} / \mathrm{L})$ with mannitol $(0.04 \mathrm{~mol} / \mathrm{L})$ and BAP. In these cases, a poor regeneration of structures and few shoots was noted (Fig. 2).

After estimating the total number of shoots, the multiplication factor was determined. The coefficient value was the highest in the presence of glucose $(0.09 \mathrm{~mol} / \mathrm{L})$ or sucrose $(0.06 \mathrm{~mol} / \mathrm{L})$, both with BAP (Figs. 3,4$)$.

Before the rooted shoots were planted into the soil, the effectiveness of rhizogenesis was determined. Relatively weak root formation was observed among plants derived from media supplemented with glucose or fructose (both with $0.09 \mathrm{~mol} / \mathrm{L}$ and BAP), and rhizogenesis did not occur at all with regenerates obtained from the substrate with mannitol $(0.04 \mathrm{~mol} / \mathrm{L}+\mathrm{BAP})$ (Table 2). The highest
Fig. 2 Effect of type and concentration of given carbohydrates on cumulative shoot regeneration of sugar beet ovules during three passages (BAP-4.4 $\mu \mathrm{mol} / \mathrm{L}$ 6-benzylaminopurine)

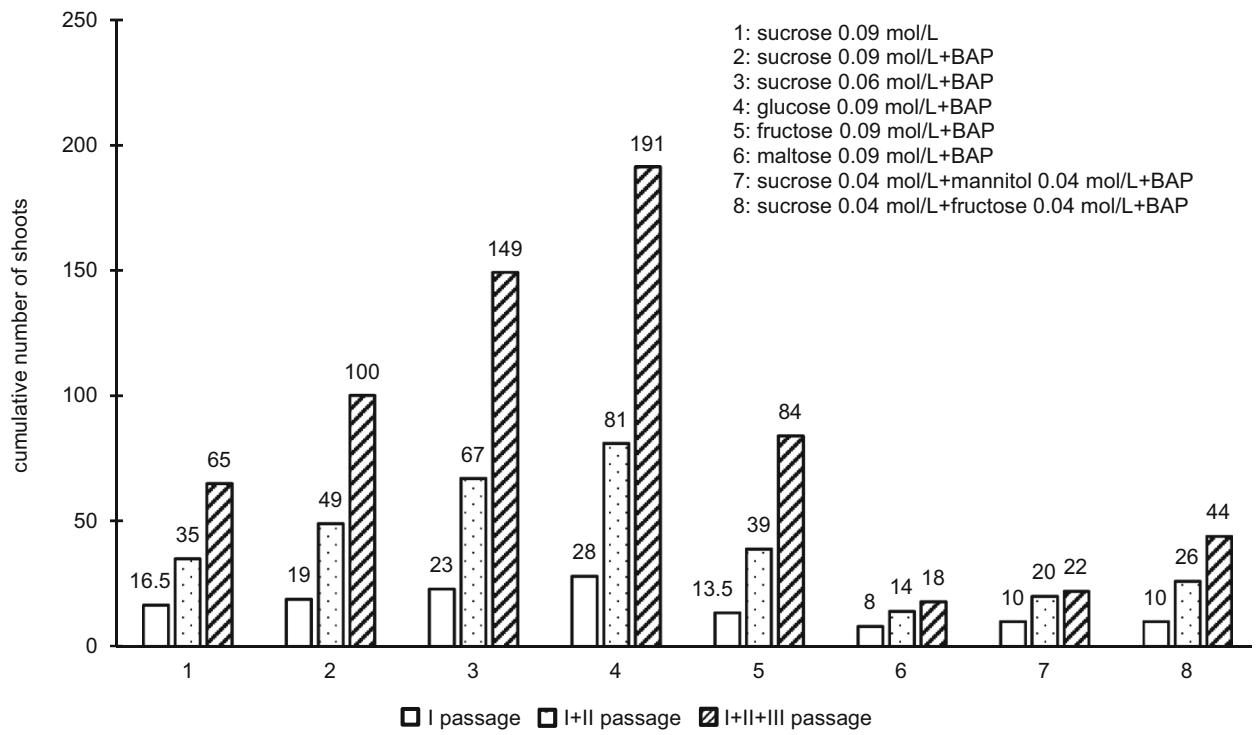


Fig. 3 Efficiency of shoot formation per explant of sugar beet ovules (BAP-4.4 $\mu \mathrm{mol} / \mathrm{L}$ 6-benzylaminopurine)

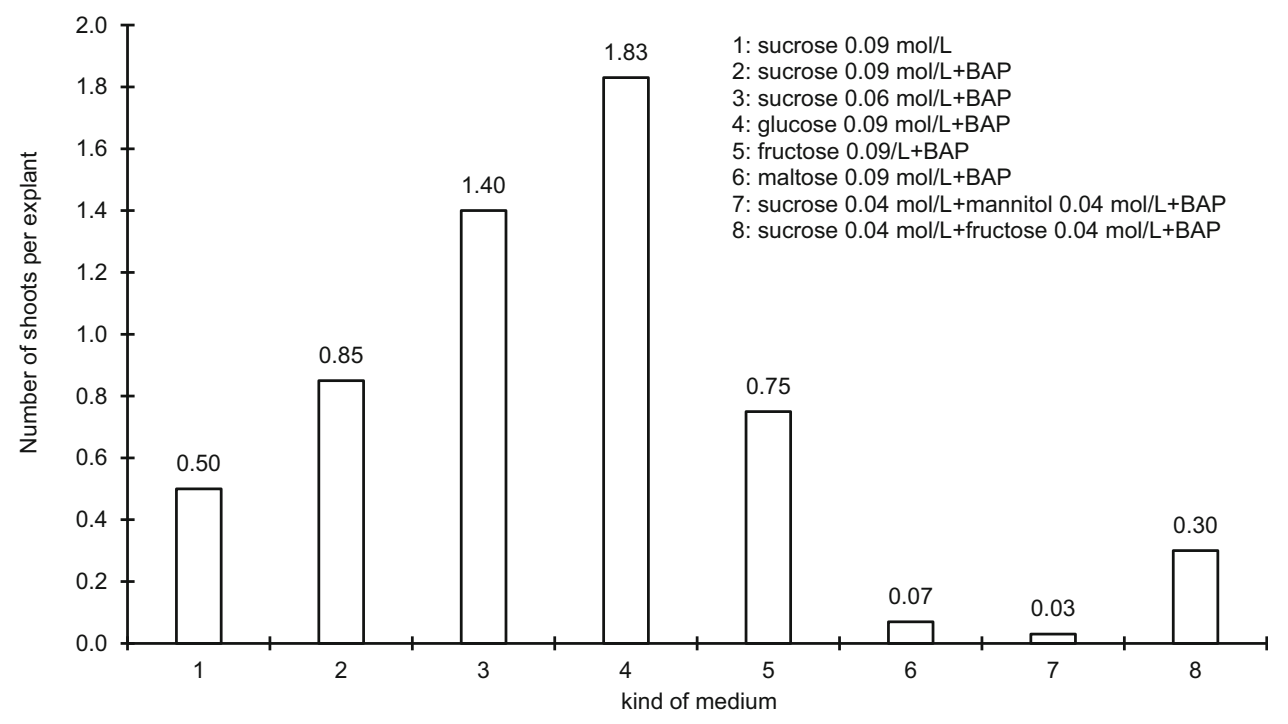

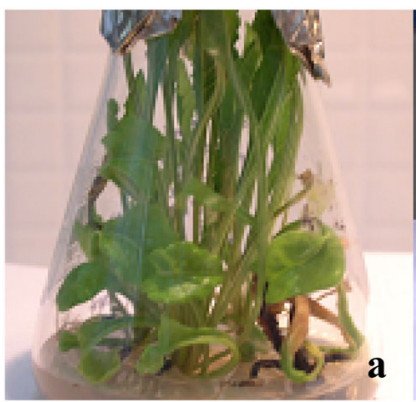

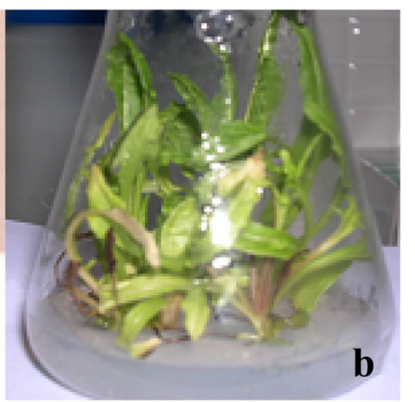

Fig. 4 Regenerated shoots on MS medium with a glucose $(0.09 \mathrm{~mol} /$ $\mathrm{L}+\mathrm{BAP}), \quad$ b sucrose $(0.06 \mathrm{~mol} / \mathrm{L}+\mathrm{BAP}) \quad(\mathrm{BAP}-4.4 \mu \mathrm{mol} / \mathrm{L}$ 6-benzylaminopurine)

percentage of rooted shoots were recorded, when the maltose $(0.09 \mathrm{~mol} / \mathrm{L}$ and $\mathrm{BAP})$ and sucrose $(0.09 \mathrm{~mol} /$ $\mathrm{L}+\mathrm{BAP}$ ) were added to the medium. The results were almost twice as high as the number of the rooted shoots

Table 2 Effect of type and concentration of carbohydrate on rooting percentage of sugar beet

\begin{tabular}{ll}
\hline Carbohydrate type & $\begin{array}{l}\text { Rooting percentage } \\
(\%)\end{array}$ \\
\hline Sucrose $0.09 \mathrm{~mol} / \mathrm{L}$ & 20 \\
Sucrose $0.09 \mathrm{~mol} / \mathrm{L}+\mathrm{BAP}$ & 25 \\
Sucrose $0.06 \mathrm{~mol} / \mathrm{L}+\mathrm{BAP}$ & 22 \\
Glucose $0.09 \mathrm{~mol} / \mathrm{L}+\mathrm{BAP}$ & 14 \\
Fructose $0.09 \mathrm{~mol} / \mathrm{L}+\mathrm{BAP}$ & 13 \\
Maltose $0.09 \mathrm{~mol} / \mathrm{L}+\mathrm{BAP}$ & 25 \\
Sucrose $0.04 \mathrm{~mol} / \mathrm{L}+$ mannitol $0.04 \mathrm{~mol} /$ & 0 \\
$\quad$ L + BAP & 22 \\
Sucrose $0.04 \mathrm{~mol} / \mathrm{L}+$ fructose $0.04 \mathrm{~mol} /$ & \\
$\quad$ L + BAP & \\
\hline
\end{tabular}

BAP-4.4 $\mu \mathrm{mol} / \mathrm{L}$ 6-benzylaminopurine growing on the medium with glucose or fructose (both $0.09 \mathrm{~mol} / \mathrm{L}+\mathrm{BAP})$. The best roots quality developed with $0.09 \mathrm{~mol} / \mathrm{L}$ sucrose + BAP. The developed roots were numerous and longer than in the other variants (Fig. 5).

The cluster analysis of 6 media (excluding the sucrose media of $0.09 \mathrm{~mol} / \mathrm{L}$ and of $0.06 \mathrm{~mol} / \mathrm{L}+\mathrm{BAP}$ ) differing in their kind and content of carbohydrates has demonstrated that the best effect on beet plant regeneration was observed for the medium with glucose $(0.09 \mathrm{~mol} / \mathrm{L}+$ BAP) (Table 3). The greatest similarity was found for the media with maltose and sucrose in combination with mannitol or fructose. The effect of those carbohydrates on the processes of organogenesis turned out to be unfavourable, which was seen from a little as indicated by the number of shoots, which were poorly rooted or did not get rooted at all (Table 3).

In order to evaluate, which concentrations of sucrose applied in the experiment are more effective in terms of a simultaneous effect on the number of formed shoots and rooted plants, the media containing sucrose at the concentrations of $0.06 \mathrm{~mol} / \mathrm{L}$ and $0.09 \mathrm{~mol} / \mathrm{L}$ were compared.

The analysis demonstrated that the differences in the effectiveness of both sucrose concentrations are small with respect to the high similarity intensity (Table 4). The methods of nonparametric statistics confirm the results obtained by counting the shoots and rooted plants.

\section{Discussion}

Carbohydrates play essential functions in plant growth and development. As building-material and reserve carbohydrates, they are the key substrates for respiration, or secondary metabolism in a number of biochemical processes. They can also protect from osmotic stress, e.g. as 


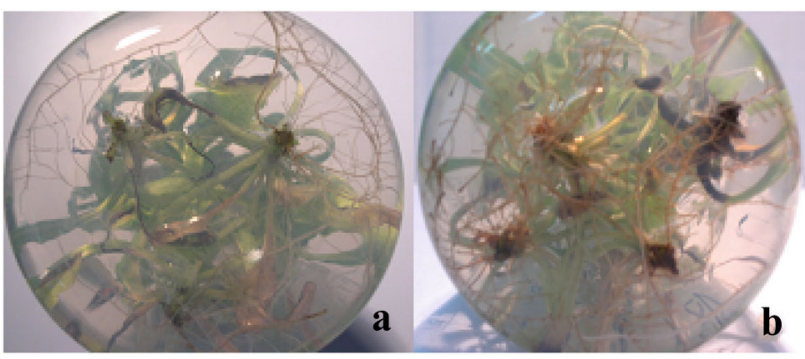

Fig. 5 Rooted plants on the MS medium with a glucose $(0.09 \mathrm{~mol} /$ $\mathrm{L}+\mathrm{BAP}), \quad$ b sucrose $(0.06 \mathrm{~mol} / \mathrm{L}+\mathrm{BAP}) \quad(\mathrm{BAP}-4.4 \mu \mathrm{mol} / \mathrm{L}$ 6-benzylaminopurine)

osmoprotectants (Ciereszko 2006). Glucose and sucrose as signalling molecules also regulate growth and the metabolism in general (van den Ende 2014; Ciereszko 2007).

The specificity of plant cultures in vitro is related to the need to supply the regenerating cells with carbohydrates as the source of carbon. The selection of the adequate type of carbohydrate depends on the plant species and the explant type. In sugar beet ovule cultures, 3\% sucrose is most frequently used (Gośka and Jassem 1988; Van Gevt et al.
1987), however, the differentiation process was recorded also in the presence of higher concentrations of that carbohydrate: 6\% (Yu 1992), 8\% (Bossoutrot and Hosemans 1985) or $10 \%$ (Gürel et al. 2000; Lux et al. 1990). The effect of sucrose seems to be dependent on the genotype. D'Halluin and Keimer (1986) found that increasing the content of sucrose to $10 \%$ decreases the regeneration capacity of explants. Similar conclusions are presented by Gośka (1997), who did not note an increase in the number of regenerating ovules on the media with $6 \%$ and $9 \%$ sucrose. However, the percentage of regenerates for the two investigated lines decreased slightly when compared with the medium with the standard dose of carbohydrate (3\%). For one of the studied genotypes, Gośka (1997) recorded a decrease of about $6 \%$ for the number of plants formed by a sucrose concentration of $3 \%$ in medium, of about $2.5 \%$ by the application of a sucrose concentration of $6 \%$ and of about $1 \%$ for a sucrose concentration of $9 \%$. Sucrose applied at the concentration of both, $3 \%$ and lower than $2 \%$, significantly increased the number of regenerated plants from 51 to 82 . Sucrose in in vitro plant cultures is usually applied at concentrations of $2-3 \%$ (Chen et al.

Table 3 Analysis of the similarity intensity of the impact of various carbohydrates in the growing media on the processes of regeneration of shoots and rooting of plants

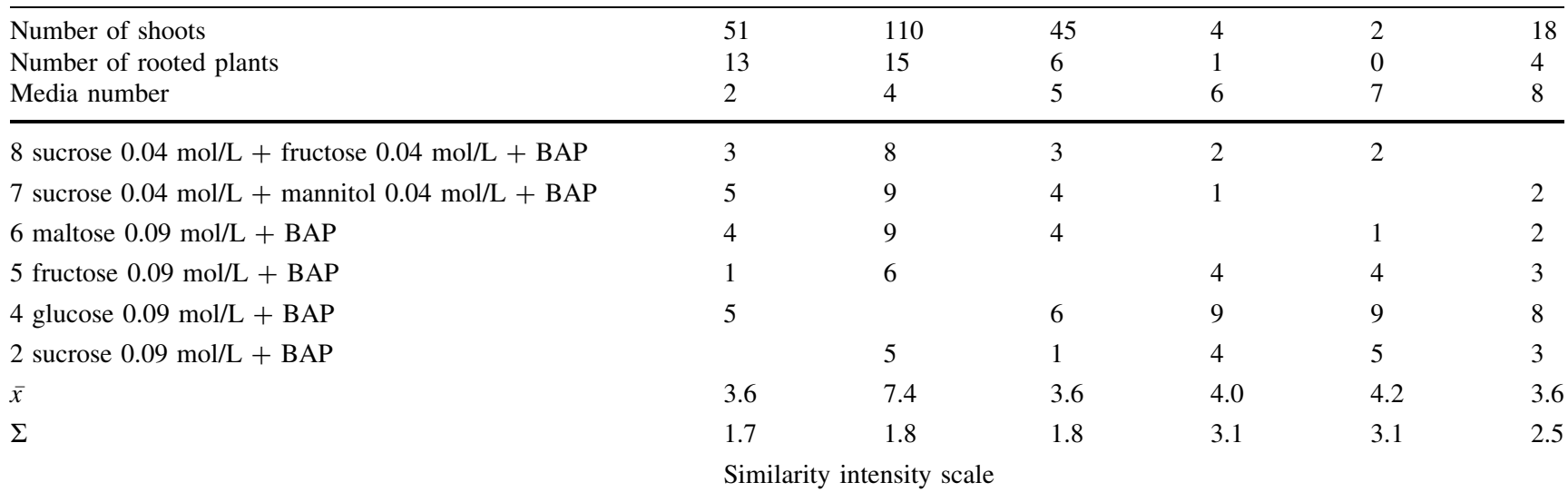

$\mathrm{BAP}-4.4 \mu \mathrm{mol} / \mathrm{L}$ 6-benzylaminopurine (BAP), similarity scale: 1 very high intensity; 9-a very poor intensity

$\bar{x}$-mean value

$\sigma$-standard deviation

Table 4 Analysis of the similarity intensity of the impact of sucrose at two concentrations on beet plant regeneration

\begin{tabular}{llll}
\hline Media number & Number of shoots & Number of rooted plants & Similarity intensity scale \\
\hline 2 sucrose $0.09 \mathrm{~mol} / \mathrm{L}+\mathrm{BAP}$ & 51 & 13 & 3 \\
3 sucrose $0.06 \mathrm{~mol} / \mathrm{L}+\mathrm{BAP}$ & 82 & 18 & \\
\hline
\end{tabular}

$\mathrm{BAP}-4.4 \mu \mathrm{mol} / \mathrm{L}$ 6-benzylaminopurine (BAP); Similarity scale: 1-very high intensity; 9-a very poor intensity 
2011). In in vitro culture of unfertilized maize Zea mays L. ovaries, initially higher concentrations $(12 \%)$ were applied (Truong-Andre and Demarly 1984). It was found that $6 \%$ sucrose enhanced the formation of embryos and inhibited the proliferation of somatic tissues in unfertilized ovary culture of wheat (Mukhambetzhanov 1992). Higher concentrations lowered the ovule development potential. When the concentration of sucrose increased to $9 \%$, the ovules did not form any embryos.

Moderately higher amounts of sucrose in the medium than the standard concentration (2-3\%) proved favourable for the cultivation and shoot induction in some plant species, e.g. carnation Dianthus caryophyllus L. (Sato et al. 2000) or sago palm Metroxylon sagu Rottb. (Sumaryono et al. 2012). In the case of carnation cultivation, numerous shoots were produced on media containing $6 \%$ of sucrose. Increasing the concentration to 9 or $12 \%$ decreased the formation and regeneration of shoots from carnation ovules (Sato et al. 2000). In marigold (Tagetes spp.) cultures, the highest percentage of callus induction from ovules $(89.7 \%)$ was noted in the presence of $4 \%$ and $6 \%$ of sucrose. A sucrose content of $4 \%$ also turned out to be most effective in terms of the callus weight, shoot formation and differentiation of shoots. A further increase in the carbohydrate concentration inhibited tissue growth. With a lack of sucrose in the medium, callus development from ovules was not induced (Thaneshwari 2018). Similar results were reported by Celebi Toprak et al. (2017), Alan et al. (2016), Burbulis et al. (2007) and Ramsay et al. (2003).

The results document also a positive effect of glucose on the number of the shoots formed, which increased to 110 . The presence of other carbohydrates in the medium, such as maltose or sucrose with mannitol or sucrose with fructose decreased the number of regenerated shoots when compared with the control. An effective organogenesis on the media with sucrose and glucose was also recorded by Ślesiak (2002), who used as explants the fragments of seedlings of rapeseed Brassica napus L. Other carbohydrates investigated by the author, e.g. maltose, did not have a significant effect on morphogenesis or, just like fructose, inhibited the regeneration processes. In princess tree [Paulownia tomentosa (Thunb.) Steud.] glucose stimulated both, proliferation and elongation of angular shoots (Litwińczuk and Bohnia 2012). However, in some cultures of thecae and in somatic embryogenesis, maltose is more favourable than sucrose. Rahman et al. (2010) suggested that this may be due to the fact that maltose does not undergo such a fast hydrolysis as sucrose. The analyses of the composition of the media made by Ślesiak (2002) also demonstrate that, while autoclaving, about $7 \%$ of sucrose breaks down to glucose and fructose. This theory is confirmed by Nuutila et al. (1997) and Georage (1993). During the culture, the content of sucrose decreased, which is the result of natural hydrolysis as a consequence of in vitro technic. In case of maltose in the medium, the content of that carbohydrate also decreased with time and this loss was balanced by an increasing amount of glucose. Plants of chrysanthemum Chrysanthemum $\times$ grandiflorum (Ramat.) Kitam. most effectively regenerated in the presence of sucrose, glucose and fructose, while other carbohydrates such as maltose, mannose, galactose and mannitol were less effective (Teixeira da Silva2004). In potato cultures, Rahman et al. (2010) demonstrated species-specific responses of plants to various kinds of carbohydrates. Differences were noted especially in plant height and fresh weight. The in tissue cultures observed differentiation in induction and development rates may be interpreted as an after-effect of the ingredients in the media. In banana cultures (Musa sp.), the most effective shoot development was induced on media with sucrose, even multiplied in the presence of 3\% sucrose and 3\% glucose (Madhulatha et al. 2006).

The differences in the effect of carbohydrates on the processes of differentiation and regeneration of cells in in vitro cultures are due to the fact that plants are not able to metabolise the respective carbohydrates contained in the medium at the same intensity. Of all the analysed media, those with $4.4 \mu \mathrm{mol} / \mathrm{L} \mathrm{BAP}$, solidified with $0.7 \%$ agar, additionally containing $0.09 \mathrm{~mol} / \mathrm{L}$ glucose or $0.06 \mathrm{~mol} / \mathrm{L}$ sucrose turned out to be optimal for shoot regeneration. On those media, more than three times as many shoots were achieved when compared with the control medium.

Of the media analysed, which differed in their type and carbohydrates content for intensifying the processes of shoot regeneration, the medium supplemented with $4.4 \mu \mathrm{mol} / \mathrm{L}$ BAP and $0.09 \mathrm{~mol} / \mathrm{L}$ glucose, solidified with $0.7 \%$ agar, turned out to be the best.

Funding Open access funding provided by University of Natural Resources and Life Sciences Vienna (BOKU), Austria.

Open Access This article is licensed under a Creative Commons Attribution 4.0 International License, which permits use, sharing, adaptation, distribution and reproduction in any medium or format, as long as you give appropriate credit to the original author(s) and the source, provide a link to the Creative Commons licence, and indicate if changes were made. The images or other third party material in this article are included in the article's Creative Commons licence, unless indicated otherwise in a credit line to the material. If material is not included in the article's Creative Commons licence and your intended use is not permitted by statutory regulation or exceeds the permitted use, you will need to obtain permission directly from the copyright holder. To view a copy of this licence, visit http://creativecommons.org/licenses/by/4.0/. 


\section{References}

Alan, A.R., F. Celebi Toprak, and A. Kaska. 2016. Production and evaluation of gynogenic leek (Allium ampeloprasum L.) plants. Plant Cell, Tissue and Organ Culture 125 (2): 249-259. https://doi.org/10.1007/s11240-016-0944-2.

Baskaran, P., and N. Jayabalan. 2005. Role of basal medium, carbon source and growth regulator in micropropagation of Eclipta alba-A valuable medicinal herb. Kmitl Science Journal 5: 469-682.

https://li01.tci-thaijo.org/index.php/cast/article/view/166580/ 120299.

Bossoutrot, D., and D. Hosemans. 1985. Gynogenesis in Beta vulgaris L.: From in vitro culture of unpollinated ovules to the production of doubled haploid plants in soil. Plant Cell Report 4: 300-303. https://doi.org/10.1007/BF00269883.

Burbulis, N., A. Blinstrubienè, A. Sliesaravičius, and R. Kuprienè. 2007. Some factors affecting callus induction in ovary culture of flax (Linum usitatissimum L.). Biologija 2(53): 21-23. http://www.elibrary.lt/resursai/LMA/Biologija/Bio72/9.pdf.

Cappadocia, M., L. Chretien, and G. Laublin. 1988. Production of haploids in Gerbera jamesonii via ovule culture: influence of fall versus spring sampling on callus formation and shoot regeneration. Canadian Journal of Botany 66: 1107-1110. https://doi.org/10.1139/b88-158.

Celebi Toprak, F., S. Akgün, and A.R. Alan. 2017. Importance of sucrose in gynogenesis induction in two Turkish leek (Allium ampeloprasum var. porrum) Lines. The 3rd International Symposium on EuroAsian Biodiversity 98. https://elib.bsu.by/bitstream/123456789/179995/1/p133.pdf.

Chand, S., and A.K. Sahrawat. 2007. Embryogenesis and plant regeneration from unpollinated ovary culture of Psoralea corylifolia. Biologia Platarum 51: 223-228. https://doi.org/10.1007/s10535-007-0045-5.

Chen, J.F., L. Cui, A.A. Malik, and K.G. Mbira. 2011. In vitro haploid and dihaploid production via unfertilized ovule culture. Plant Cell, Tissue and Organ Culture 104 (3): 311-319. https://doi.org/10.1007/s11240-010-9874-6.

Ciereszko, I. 2006. Sucrose metabolism control in plants as response to changes of environmental conditions Kosmos 55: 229-241. http://kosmos.icm.edu.pl/PDF/2006/229.pdf.

Ciereszko I. 2007. Sugar sensing and signal transduction in plant cells. Postępy Biologii Komórki (in Polish) 34: 695-713. https://www.pbkom.eu/sites/default/files/artykulydo2012/ 34_4_695.pdf.

D'Halluin, K., and B. Keimer. 1986. Production of haploid sugar beets (Beta vulgaris L.) by ovule culture. In: Genetic manipulation in plant breeding (red. Horn W., Jensen C.K., Odenback W., Schieder O.). Walter de Gruyter and Co. Berlin, New York, 307-309.

Doctrinal, M., R.S. Sangwan, and B.S. Sangwan-Norreel. 1989. In vitro gynogenesis in Beta vulgaris L.: Effects of plant growth regulators, temperature, genotypes and season. Plant Cell, Tissue and Organ Culture 17: 1-12. https://doi.org/10.1007/BF00042276.

Doctrinal, M., R.S. Sangwan, B.S. Sangwan-Norreel. 1990. Sugarbeet (Beta vulgaris L.): In vitro induction of haploids. In: Haploids in Crop Improvement I. Biotechnology in Agriculture and Forestry, eds Y.P.S. Bajaj, 12: 346-357, Berlin, Heidelberg: Springer. https://doi.org/10.1007/978-3-642-61499-6_17.

George, E.F. 1993. Plant propagation by tissue culture, part 1. The Technology. Exegetics Ltd England.

Gonzalez, J.M., E. Friero, and N. Jouve. 2001. Influence of genotype and culture medium on callus formation and plant regeneration from immature embryos of Triticum turgidum Dest, Cultivars.
Plant Breeding 120: 513-517.

https://doi.org/10.1046/j.1439-0523.2001.00661.x.

Gonzalez, J.M., and N. Jouve. 2000. Improvement of anther culture media for haploid production in triticale. Cereal Research Communications 28: 65-72. https://doi.org/10.1007/BF03543575.

Gośka, M. 1997. Haploidy i podwojone haploidy buraka cukrowego (Beta vulgaris L.) oraz możliwości ich wykorzystania w hodowli. Monografie i rozprawy naukowe IHAR, $\mathrm{Nr} 2$.

Gośka, M., and B. Jassem. 1988. Histological observations of sugarBeet ovules in in vitro cultures. . Bulletin of the Polish Academy of Sciences. Biology 36: 171-175.

Gürel, S., E. Gürel, and Z. Kaya. 2000. Doubled haploid plant production from unpollinated ovules of sugar beet (Beta vulgaris L.). Plant Cell Report 19: 1155-1159. https://doi.org/10.1007/s002990000248.

Hosemans, D., and D. Bossoutrot. 1983. Induction of haploid plants from in vitro culture of unpollinated beet ovules (Beta vulgaris L.). Zeitschrift Fur Pflanzenzüchtung 91: 74-77.

Hosemans, D., and D. Bossoutrot. 1985. In vitro culture of unpollinated beet (Beta vulgaris L.) ovules of male sterile and male fertile plants and induction of haploid plants. In: Experimental Manipulation of Ovule Tissues. Plant Science. Eds G.P. Chapmann, S.H. Mantell, and R.W. Daniels, 79-88, New York: Longman.

Javed, F., and S. Ikram. 2008. Effect of sucrose induced osmotic stress on callus growth and biochemical aspects of two wheat genotypes. Pakistan Journal of Botany 40:1487-1495. http://pakbs.org/pjbot/PDFs/40(4)/PJB40(4)1487.pdf.

Kim, S.W., B.W. Min, and J.R. Lin. 1999. High frequency plant regeneration from immature ovule-Derived embryogenic cell suspension cultures of Chelidonium majus var asiaticum. Plant Cell, Tissue and Organ Culture 56: 125-129. https://doi.org/10.1023/A:1006210205704.

Litwińczuk, W., and E. Bochnia. 2012. Development of royal paulownia (Paulownia tomentosa Steud.) in vitro shoot cultures under the influence of different saccharides. Acta Scientiarum Polonorum, Hortorum Cultus 11(2) 3-13. http://www.hortorumcultus.actapol.net/pub/11_2_3.pdf.

Lux, H., L. Herrmann, and C. Wetzel. 1990. Production of haploid sugar beet (Beta vulgaris L.) by culturing unpollinated ovules. Plant Breeding 104: 177-183. https://doi.org/10.1111/j.1439-0523.1990.tb00420.x.

Madhulatha, P., S.I. Kirubakaran, and N. Sakthivel. 2006. Effects of carbon sources and auxins on in vitro propagation of banana. Biologia Plantarum 50: 782-784. https://doi.org/10.1007/s10535-006-0131-0.

Mezei, S., L. Kovacev, and N. Nagl. 2006. Sugar beet micropropagation. Biotechnology and Biotechnological Equipment 20 (1): 9-14. https://doi.org/10.1080/13102818.2006.10817296.

Mukhambetzhanov, S.K. 1992. Growth and morphogenesis of nonfertilized ovaries of wheat in vitro. Ph.D thesis, Main. Botanical Garden, Academy of Kazakstan, Alma-Ata.

Murashige, T., and F. Skoog. 1962. A revised medium for rapid growth and bio assays with tobacco tissue cultures. Physiologia $\begin{array}{llll}\text { Plantarum } & 15 & \text { (3): } & 473-497 .\end{array}$ https://doi.org/10.1111/j.1399-3054.1962.tb08052.x.

Musiał, K., and L. Przywara. 2001. Gynogeneza u roślin (Gynogenesis in plants). Kosmos. Problemy Nauk Biologicznych 50(1-2): 39-48. http://kosmos.icm.edu.pl/PDF/2001/39.pdf.

Nuutila, A.M., A.S. Lindqvist, and V. Kauppinen. 1997. Growth of hairy root cultures of strawberry (Fragaria $\times$ ananassa Duch) in three different types of bioreactors. Biotechnology 11: 363-366. https://doi.org/10.1023/A:1018444117681.

Pazuki, A., F. Aflaki, E. Gürel, A. Ergül, and S. Gürel. 2018. Gynogenesis Induction in Sugar Beet (Beta vulgaris) Improved 
by 6-Benzylaminopurine (BAP) and Synergized with Cold Pretreatment. Sugar Tech 20 (1): 69-77. https://doi.org/10.1007/s12355-017-0522-X.

Rahman, M.H., R. Islam, M. Hossain, and M.S. Islam. 2010. Role of sucrose, glucose and maltose on conventional potato micropropagation. Journal of Agricultural Technology 6(4): 733-739. http://www.ijat-aatsea.com/pdf/October_v6_n4_10/10-106IJAT2009_86R.pdf.

Ramsay J.L., D.S. Galitz, and C.W. Lee. 2003. Basal medium and sucrose concentration influence regeneration of Easter Lilly in ovary culture. Hort Science 38(3):404-406. https://doi.org/10.21273/HORTSCI.38.3.404.

Roberts-Ochschlager, S.L., J.M. Dunwell, and R. Foulks. 1990. Changes in the sugar content of barley anthers during culture on different carbohydrates. Plant Cell, Tissue and Organ Culture 22 (2): 77-83. https://doi.org/10.1007/BF00043682.

San Noeum, L.H. 1976. Haploides d'Hordeum vulgare L. par culture in vitro non fécondés. Annales de l'amélioration des plantes 26: 751-754.

Sato, S., N. Katoh, H. Yoshida, S. Iwail, and M. Hagimori. 2000. Production of doubled haploid plants of carnation (Dianthus caryophyllus L.) by pseudofertilized ovule culture. Scientia Horticulturae 83: 301-310. https://doi.org/10.1016/S0304-4238(99)00090-4.

Slama-Ayed, O., and H. Slim-Amara. 2007. Production of doubled haploids in durum wheat (Triticum durum Desf.) through culture of unpollinated ovaries. Plant Cell, Tissue and Organ Culture 91: 125-133. https://doi.org/10.1007/s11240-007-9281-9.

Sumaryono, W. Muslihatin., and D. Ratnadewi. 2012. Effect of carbohydrate source on growth and performance of in vitro sago palm (Metroxylon sagu Rottb.) plantlets. HAYATI Journal of Biosciences 19 (2): 88-92. https://doi.org/10.4308/hjb.19.2.88.

Ślesiak, H. 2002. Wpływ cukrów na rozwój zarodka, produkcję kalusa i regenerację in vitro u wybranych odmian rzepaku (Brassica napus L.). Praca doktorska. Uniwersytet Jagielloński. Wydział Biologii i Nauk o Ziemi, Instytut Botaniki, Kraków, Poland.

Taghipour, F., N. Janalizadeh, M. Eshrati, T. Hassanzadeh, and F. Huyop. 2013. Callus induction and shoot organogenesis in two sugar beet (Beta vulgaris L.) breeding lines in vitro cultured. Biotechnology $\quad 12 \quad$ (4): $\quad 168-178$. https://doi.org/10.3923/biotech.2013.168.178.

Teixeira Da Silva, J.A. 2004. The effect of carbon source on in vitro organogenesis of chrysanthemum thin cell layers. Bragantia 63: 165-177. https://doi.org/10.1590/S0006-87052004000200002.

Thaneshwari, C.A. 2018. Effect of plant growth regulators and sucrose concentration on callus induction and shoot differentiation from ovary culture of marigold (Tagetes spp). International Journal of Chemical Studies 6(1): 618-623.
http://www.chemijournal.com/archives/2018/vol6issue1/PartI/56-310-810.pdf.

Tomaszewska-Sowa, M. 2012. Effect of growth regulators and other components of culture medium on morphogenesis of sugar beet (Beta vulgaris L.) in unfertilised ovule in vitro cultures. Acta Agrobotanica 65: 91-100. https://doi.org/10.5586/aa.2012.025.

Tomaszewska-Sowa, M., A. Figas, and A. Gatz. 2017. Histological analysis of organogenesis and somatic embryogenesis during shoot formation in sugar beet (Beta vulgaris $\mathrm{L}$.) via gynogenesis. Polish Journal of Natural Sciences 32(4): 705-717. http://www.uwm.edu.pl/polish-journal/sites/default/files/issues/ articles/tomaszewska-sowa_et_al._2017.pdf.

Tomaszewska-Sowa, M., and D. Olszewska. 2019. Evaluation of genetic stability of sugar beet (Beta vulgaris L.) plants obtained from unfertilized ovules using RAPD markers. Journal of Central European Agriculture 20 (3): 928-937. https://doi.org/10.5513/JCEA01/20.3.2175.

Truong-Andre, I., and Y. Demarly. 1984. Obtaining plants by in vitro culture of unfertilized maize ovaries (Zea mays L.) and preliminary studies on the progeny of gynogenetic plant. $Z$ Pflanzenzucht 92: 309-320.

Van den Ende, W. 2014. Sugars take a central position in plant growth, development and stress responses. A focus on apical dominance. Frontiers in Plant Science 5: 313. https://doi.org/10.3389/fpls.2014.00313.

Van Geyt, J., G.J. Spockmann Jr., K.D. Halluin, and M. Jacobs. 1987. In vitro induction of haploid plants from unpollinated ovules and ovaries of the sugar beet (Beta vulgaris). Theoretical and $\begin{array}{llll}\text { Applied } & \text { Genetics } & 73 & \text { (6): }\end{array}$ https://doi.org/10.1007/BF00289399.

Wang, S., A. Hang, and T. Tsuchiya. 1991. Chromosome studies of callus tissues and regenerated plants from an unfertilized ovule culture of sugarbeet (Beta vulgaris L.). Journal of Genetics and Breeding 45: 161-168.

Wremeth Weich, E., and M.W. Levall. 2003. Doubled haploid production of sugar beet (Beta vulgaris L.). In: Doubled haploid production in crop plants. A manual, eds. M. Maluszynski, K.J. Kasha, B.P. Forster, and I. Szarejko, 255-263. Springer Netherlands. https://doi.org/10.1007/978-94-017-1293-4.

Yang, H.Y., and C. Zhou. 1982. In vitro induction of haploid plants from unpollinated ovaries and ovules. Theoretical and Applied Genetics 63: 97-104. https://doi.org/10.1007/BF00303687.

$\mathrm{Yu}$, M.H. 1992. Growth and reproduction performance of ovuleInduced sugar beet plants. Sabrao Journal of Breeding and Genetics 24 (1): 47-55.

Publisher's Note Springer Nature remains neutral with regard to jurisdictional claims in published maps and institutional affiliations. 